\title{
9 Procedural justice, relational equality, and self-respect
}

\author{
Catriona Mackenzie
}

\subsection{Introduction ${ }^{1}$}

The literature on procedural justice (hereafter PJ) in social psychology has amassed a significant body of empirical evidence showing the importance of relational considerations, both to citizens' views about what makes the use of power and authority in legal and organisational contexts legitimate and to citizens' willingness to comply with the law and to cooperate with police, administrative, and legal authorities. ${ }^{2}$ This literature has shown that people care as much, if not more, about how authorities exercise power and make decisions as they do about the actual decisions that are made. ${ }^{3}$ Specifically, people care about whether administrative and legal processes are fair, and they care about the attitudes expressed by police, administrative and legal authorities in their interactions with the public. What emerges from the empirical findings is that four factors really matter to people in their dealings with authorities: that authorities 'treat citizens in a fair and respectful way, make neutral and unbiased decisions, display trustworthy motives, and allow the citizen a voice in their interactions' (Jackson 2018, p. 4). These four factors influence the extent to which people view police, legal and administrative authorities as legitimate, the extent to which people are likely to obey the law, and the extent to which they are motivated to cooperate with these authorities.

Insofar as the social psychology literature is concerned with people's perceptions of legitimacy it operates with a descriptive or sociological conception of legitimacy, according to which a set of institutions 'is legitimate ... if those subject to its directives widely believe it to enjoy the moral right to rule' (Levitov 2016, p. 1, emphasis in original). This sociological conception of legitimacy should be distinguished from a prescriptive or normative conception of legitimacy, according to which a set of institutions is legitimate 'if it in fact enjoys the moral right to rule over those it claims the authority to govern' (Levitov 2016, p. 1, emphasis in original). Social psychologists do not explicitly address the question of whether the four elements of PJ (respect, neutrality, trustworthiness, and voice) provide criteria for assessing the normative legitimacy of police, legal, or administrative authorities, although this claim does seem to be implicit in some of the literature on PJ. At the very least, however, an implication of the empirical research is that

DOI: $10.4324 / 9780429317248-13$ 
citizens are more likely to confer legitimacy on police and legal authorities (and hence to consent to their use of power) if they judge that those authorities are behaving in line with citizens' normative expectations. Hence, if authorities want to be perceived as legitimate (i.e. to be legitimate in the descriptive sense), they should take steps to ensure that the four elements of PJ are embedded in legal and administrative processes and that they guide officials in their interactions with citizens.

Several different kinds of justification for the view that authorities should try to satisfy citizens' procedural expectations by attending to the four elements of PJ are suggested, but not clearly distinguished, in the empirical literature. One kind of justification appeals to people's psychological motivations for voluntarily complying and cooperating with authorities, explicitly linking these motivations to the four elements of PJ. Tyler and Lind (1992), for example, claim:

The belief that the authority views one as a full member of society, trust in the authority's ethicality and benevolence, and belief in the authority's neutrality-these appear to be the crucial factors that lead to voluntary compliance with the directives of authority.

Tyler and Lind explain the link between PJ and psychological motivations to cooperate and comply via group-value theory. Group-value theory contends that relational concerns are central to people's judgements about procedural justice. According to the theory, people's sense of self-identity is based on their membership in valued groups, and they are very attuned to their perceived standing or status in such groups. For this reason, people are highly sensitive to the messages about their status conveyed by group processes and by how they are treated by persons in positions of authority:

To the extent that a procedure is seen as indicating a positive, full status relationship, it is judged to be fair, and to the extent that a procedure appears to imply that one's relationship with the authority or institution is negative or that one occupies a low-status position, the procedure is viewed as unfair.

The empirical research provides strong evidence that procedures embodying the four elements of PJ are more likely to be perceived as fair. Hence, if authorities want to be perceived as legitimate and if they want to secure cooperation and compliance, they should ensure their processes are responsive to people's relational concerns.

This justification for why authorities should be concerned about PJ admits of both an instrumental and a normative interpretation. The instrumental interpretation is that authorities, such as police, should be responsive to people's relational concerns and hence should embed PJ in their interactions with citizens 
because approaches based on PJ are more effective than other methods of law enforcement, such as deterrence based strategies that rely on coercion or reward mechanisms. While deterrence based strategies rely on motivations such as fear of punishment or self-interest, PJ is more effective, it is claimed, because it is more likely to encourage belief in the legitimacy of authorities, and to promote the internalisation of legal norms and voluntary compliance with the law (see, e.g., Tyler 2009). ${ }^{4}$ The normative interpretation is that authorities should be responsive to people's relational concerns and hence should embed PJ in their interactions with citizens because it is morally right that citizens are treated in a procedurally just manner. Both the instrumental and the normative interpretation are invoked by social psychologists. However, to the extent that they do invoke the normative interpretation, social psychologists tend to assume, rather than argue for the normative correctness of PJ.

My aim in this chapter is to develop an argument in support of the normative interpretation. I argue that there are good normative reasons why people care about their standing in social groups and why citizens are more likely to perceive authorities as legitimate and to cooperate with them if these authorities treat them fairly and respectfully, are neutral and trustworthy, and allow them a voice in their interactions. I also argue that authorities should be responsive to people's relational concerns and hence should embed PJ in their interactions with citizens because it is morally right that citizens are treated in a procedurally just manner by social institutions and their representatives. The moral correctness of PJ, I claim, is connected with its role in expressing attitudes of respect and supporting ideals of social equality among citizens. If this argument is persuasive, it also suggests that legitimacy in the descriptive or sociological sense provides the basis for legitimacy in the normative sense.

In developing this argument in the following sections, I draw on the resources of recent work in normative political philosophy. In Section 9.2, I discuss recent philosophical theories of relational equality and outline their relevance for articulating a normative argument for a relational approach to PJ, as it is understood in the empirical literature. In Section 9.3, I discuss Emanuela Ceva's (2016) recent 'interactive theory' of PJ, which articulates a normative conception of procedural equality and presents an argument for why states have obligations to ensure that interactions between authorities and citizens, and among citizens, are procedurally just. In Section 9.4, I briefly outline two influential views in moral philosophy that link the normative requirement of respect for others to the normative and psychological importance of self-respect. I conclude by explaining why the view defended in this chapter lends support to the idea that legitimacy in the descriptive sense may provide the basis for legitimacy in the normative sense.

\subsection{Relational equality and procedural justice}

Reviewing the empirical literature on procedural justice in tandem with recent debates in normative political philosophy reveals an interesting parallel shift in both literatures towards more relational conceptions of justice. To start with a 
very broad outline, philosophical theories of relational ethics and justice uphold the normative importance of individual rights, welfare, dignity, and autonomy (Anderson 2009, p. 132). However, these theories reject social atomism. They hold that we are social beings whose individual identities are constituted through interpersonal relationships and in the context of the broader social and political environments in which we live. Our self-identities and sense of self-respect are therefore necessarily shaped by and vulnerable to the quality of our interpersonal relationships and our interactions with social institutions. Relational theories of ethics and justice draw specific attention to the moral significance of social oppression, marginalisation, and inequalities of social power and standing, and their effects on individuals' self-identities, autonomy, and sense of self-respect.

Theories of relational equality are relational in this broad sense. More specifically, relational egalitarian theorists, such as Elizabeth Anderson (1999, 2008), Jonathon Wolff $(1998,2015)$, and Samuel Scheffler $(2003,2015)$, among others, have argued that the preoccupation among post-Rawlsian liberal political philosophers with distributive justice fails to appreciate the real point of liberalism's concern with equality. For these philosophers, concerns about equality are not only, or not primarily about minimising gross inequalities in the distribution of social goods and resources, but more importantly about relational or social equality. Liberal political philosophers take one of the foundational principles of liberalism to be that people should be treated as moral equals. Theories of distributive justice assume that the best interpretation of this principle of moral equality is that people should be equally entitled to fair shares of the currency of justice. Debates in the post-Rawlsian literature have focused almost exclusively on the question of how best to conceptualise this currency or metric-e.g. welfare, resources, opportunity, or capabilities. These debates have done much to clarify the differences between equality of welfare, equality of resources, equality of opportunity, and equality of capabilities. Yet, the exclusive focus in these debates on questions concerning what distributive shares people are entitled to has overlooked other important dimensions of justice.

Relational egalitarian theories do not dismiss distributive considerations as unimportant for justice. However, they claim that justice is about more than patterns of distribution. It is more fundamentally about social equality. Relational egalitarianism can be expressed both as a positive ideal of social equality and as a critique of social inequality. In articulating a positive ideal of social equality, Samuel Scheffler, for example, characterises social equality as a broad and complex ideal, bound up with other values such as respect and reciprocity. At its core is the ideal of a society of equals: 'justice requires the establishment of a society of equals, a society whose members relate to one another on a footing of equality' $(2015$, p. 21$)$. The ideal of a society of equals directs the focus of concerns about justice from purely distributive concerns to concerns about the structure and character of social relationships. In a just society, Scheffler argues, the idea of social equality should shape the attitudes and dispositions of both institutions and individuals in their interpersonal relationships, so that commitment to equality becomes a social practice. Central to this practice is a reciprocal commitment to 
respect others, a commitment to a common social framework, and commitment to participatory decision-making procedures where no person's interests (values, needs, preferences) are discounted without due consideration.

Similarly, Elizabeth Anderson articulates a positive ideal of social equality that she refers to as 'democratic equality'. Anderson claims that the fundamental obligation of citizens in a democratic state towards one another is to secure the social conditions for everyone's freedom. This requires, in her view, 'a social order in which persons stand in relations of equality' and respect (1999, p. 313), because 'the counterpart to an individual's inalienable right to the social conditions of her freedom is the unconditional obligation of others to respect her dignity or moral equality' (p. 319). A social order based on this kind of reciprocal respect is one in which all citizens have equal access to the capabilities required to participate in a democratic state, not only in the political sphere, but also in civil society. It is a social order that expresses respect for citizens, and in which state institutions and citizens feel an obligation 'to justify their actions by principles acceptable to the other' and in which 'mutual consultation, reciprocation, and recognition' are taken for granted (p. 314). In other words, such a social order is a democratic community of collective self-determination and cooperation. ${ }^{5}$

Perhaps of more fundamental concern to relational egalitarians than the articulation of a positive ideal of social equality is the importance of exposing and criticising social inequality and the harms it causes. Jonathan Wolff (2015) argues, for example, that the primary theoretical and epistemological task of political philosophy should not be to formulate ideals of justice but to identify and criticise manifest injustices. He suggests that the main contribution of relational egalitarian theory is not the articulation of an ideal of social equality but rather the way it draws attention to social inequality as one of the primary causes of injustice. For relational egalitarians, social inequality is characterised by social hierarchies of rank and esteem, and by social institutions, norms and relationships that entrench social relations of oppression, exploitation, domination and subordination. These kinds of inequalities of status and standing are inherently unjust, according to relational egalitarians, because, as Anderson (2008) puts it, they are 'degrading, humiliating and assaultive of individuals' status as beings entitled to moral standing before others' (p. 142).

Further, status inequalities undermine the mutual respect and recognition that should characterise social relationships in democratic communities. Entrenched social inequalities cause a range of harms to those who are on the receiving end of attitudes of social disrespect and disregard. These harms include being subject to social stigma and exclusion, being distrusted, being silenced, ignored, or regarded as not credible in discursive and testimonial contexts, being required to act towards one's social superiors in ways that one finds demeaning, servile and shameful, and being vulnerable to violence.

Two key concerns of relational egalitarianism are particularly important to note at this point. First, relational egalitarians hold that a central commitment of liberalism should be to ensure equality of access to the social bases of self-respect. Entrenched social inequality, they maintain, undermines this commitment 
because social disrespect and the harms that it causes also damage self-respect (Garrau \& Laborde, 2015 pp. 49, 57). I will return to this issue in Section 9.4. Second, relational egalitarians are particularly concerned with the expressive role of state institutions. They hold that state institutions have special responsibilities to ensure that their processes express respect for citizens, and that, in their interactions with citizens, office holders treat individuals in ways that convey attitudes of equal respect. Christian Schemmel (2011) notes that the expressive demand is not just a matter of what the institution or its agents meant to express by their actions, but also a matter of 'how those subject to the action may reasonably understand it' (p. 138). Wolff is especially critical, for example, of the way the social welfare system in the UK routinely subjects welfare recipients to demeaning and intrusive forms of expressive disrespect. ${ }^{6}$ However, expressive respect is not just a matter of the attitudes conveyed by legal or bureaucratic processes and office holders; it is also a matter of what structural protections institutions put in place to mitigate social inequality and the vulnerabilities and harms it causes. As Schemmel puts the point,

institutions treat individuals with the proper attitude when they offer them adequate and equal structural protection against unjust treatment by other individuals, against ending up on the wrong side of inegalitarian relationships.

Relational egalitarians maintain that to be just, social institutions must ensure that individuals are not dominated by others, that others cannot interfere with their choices in an arbitrary manner' (p. 142).

Given this critique of social inequality, one of the questions that relational egalitarian theory needs to address is what it has to say about the inescapable hierarchies of authority and command in complex modern societies. For it is these kinds of social hierarchies that, in democratic societies, often threaten people's status as social equals, and expose them to relations of domination, social stigma and disrespect. In addressing this question, Anderson (2008) makes a useful distinction between three kinds of unequal social hierarchies (pp. 144-145): i) hierarchies of standing, which deny rights and privileges, or grant inferior rights and privileges, to those at the bottom of the social hierarchy; ii) hierarchies of esteem, where those at the top 'command honour and admiration, while those below are stigmatized and held in contempt, as objects of ridicule, loathing, or disgust'; and hierarchies of command, 'of domination and subordination, whereby those at the top issue orders to those below, who must defer and obey' (p. 145). 'Egalitarians aim', she says, 'to the extent possible, to abolish such hierarchies and replace them with relations of equality'.

While state-sanctioned hierarchies of standing, such as those based on class, caste, gender, race or ethnicity can be abolished through constitutional and legislative measures, it is more challenging to abolish the hierarchies of esteem that are typically associated with unofficial hierarchies of standing in civil society. Nevertheless, these must be the focus of sustained egalitarian critique. The same 
applies to hierarchies of command when these are not required for coordinating social functions. But what should relational egalitarians say about the hierarchies of command that are required for coordinating complex social functions, such as command hierarchies in bureaucracies, courts and legal systems, the police, the military, corporations, and other large workplaces? These kinds of hierarchies may be rationally required to ensure social order and cooperation, but are they normatively justifiable? Relational egalitarians hold that such hierarchies can be normatively justified if they meet the requirements of legitimacy. To count as legitimate, institutions and command hierarchies must first abide by principles of non-domination. What this entails is that state institutions have obligations to ensure that the differential power, authority and status attached to office holders in these kinds of command hierarchies do not enable them to wield arbitrary power and dominate those who are subject to their commands. As Schemmel puts the point:

in successful social cooperation, power must, most of the time, not be exercised in the form of naked coercion but in the form of commands and directives on the part of holders of offices and occupants of privileged social positions whose legitimacy is generally recognized by those subject to their power.

A further requirement of legitimacy, as this quote from Schemmel suggests, is that differences in the exercise of power and authority arising from command hierarchies can only be normatively justified if institutions and the authorities who represent them are recognised as legitimate by those who are subject to them; that is, if they are legitimate in the descriptive or sociological sense. This requires that institutions put in place mechanisms or processes by which those who exercise power can be held publicly accountable for their actions and decisions, and those who are subject to that power are able to voice and defend their interests.

This brief summary of relational egalitarian theory provides a starting point for explaining how relational egalitarian theories of justice might be used to provide normative support for relational approaches to PJ. Relational egalitarianism, as outlined above, shifts the focus of claims about justice to the structure and character of social institutions and relationships. It claims that justice is normatively grounded in an ideal of social equality and that social inequality and domination are major sources of injustice. Social institutions therefore have normative obligations to ensure that their processes and office holders express respect for the moral and social equality of all persons; that the exercise of power and authority by office holders in command hierarchies is regarded as legitimate by the persons who are subject to it; and that mechanisms are in place both for holding institutions and office holders publicly accountable and for enabling persons who are subject to power and authority to voice their concerns and interests. 
These claims, I suggest, give normative substance to the concerns about social standing and fair treatment by authorities that emerge as strong themes in the empirical research on procedural justice. Tyler and Lind (1992) say:

Information about standing-i.e. status recognition-is often communicated to people by the interpersonal quality of their treatment by those in a position of authority. In particular, when one is treated politely and with dignity and when respect is shown for one's rights and opinions, feelings of positive social standing are enhanced ... On the other hand, undignified, disrespectful or impolite treatment by the authority carries the implication that one is not a full member of the group, and this is very threatening indeed.

(p. 141)

Tyler and Lind explain people's concerns about standing in terms of group-value theory, which focuses on people's psychological motivations. Relational egalitarianism suggests, however, that people's concerns about how they are treated by authorities, about the attitudes expressed towards them, and the messages these interactions convey about a person's social standing are not just matters of psychological motivation. These concerns are grounded in an expectation of normative entitlement to be treated as a moral and social equal, an entitlement that is violated by interactions with authorities that express disrespect. ${ }^{7}$

The four elements of PJ identified in the empirical research, I suggest, embody citizens' expectations of normative entitlement to be treated as social and moral equals. Institutions and authorities that treat people fairly and with respect, ensure that people have opportunities to participate in processes that affect them, make decisions neutrally, and act from trustworthy motives, are responsive to those expectations. The empirical research shows that institutions and authorities that are responsive in these ways are more likely to be regarded as legitimate in the descriptive sense. Relational egalitarianism helps to explain why this kind of responsiveness is normatively required, and hence why institutions and authorities that act in procedurally just ways, are normatively legitimate; namely, because procedurally just processes and interactions express respect for citizens as moral and social equals.

Given the potentially fruitful conceptual connections between relational egalitarian theories of justice and the empirical research on procedural justice, it is surprising that relational egalitarians have paid little attention to procedural justice. Nor have they said much about how institutional processes should be designed so that they both act as constraints on the arbitrary exercise of power in command hierarchies, and more positively help to foster genuine cooperation between authorities and the individuals and communities with whom they interact. In order to flesh out these conceptual connections more fully, in the following section I discuss Emanuela Ceva's recent 'interactive theory' of justice (2016). ${ }^{8}$ Like relational egalitarianism, Ceva identifies social relationships and interactions as a locus of claims of justice. However, her specific focus on procedural justice makes a distinctive contribution to the literature on justice in contemporary normative 
political philosophy, and one that is highly relevant to the argument of this chapter. I begin by providing a brief outline of Ceva's conception of procedural justice and then assess its merits and relevance, relative to relational egalitarianism, with respect to providing normative support for the findings of the empirical research on PJ.

\subsection{Ceva's 'interactive' theory of procedural justice}

Like relational egalitarian theories, Ceva (2016) argues that debates about justice in normative political philosophy have been overly focused on 'end-state justice', that is questions concerning justice in distributive shares and outcomes. However, little attention has been paid to questions of 'interactive' or procedural justice. Interactive justice is concerned with the justice or injustice of processes and procedures of social and political interaction. Ceva's specific concern in the book is with debates about intractable, antagonistic value conflicts in politics-for example, debates over abortion, or gay marriage. The problem with these kinds of conflict, she argues, is that they often expose people, especially vulnerable minorities, to inherently morally unacceptable forms of treatment, such as silencing, marginalisation, and public stigmatisation, or 'interactive injustice' (p. 15). The question that Ceva seeks to answer is how these kinds of value conflict can be shifted from antagonistic and disrespectful exchanges towards what Rawls calls 'reasonable disagreement' (Rawls 1993) - that is, forms of disagreement in which the parties do not feel disrespected or marginalised but engage with each other in a mutually respectful and trusting manner, and are open and willing to try to understand the other party's viewpoint (Ceva 2016, pp. 13-31). I will not engage in any detail with this aspect of Ceva's argument. The main focus of my discussion will be on her more general normative arguments for the importance of procedural justice. I want to highlight four main claims that are of particular relevance to my concerns in this chapter.

First, Ceva argues that outcomes and procedures are distinct social objects and raise distinct questions of justice. What matters is not only what people get but also how they get it. End-state or outcome-focused justice and interactive or procedural justice, although complementary, are therefore conceptually and normatively distinct (pp. 78-79). She says, 'procedures ... may be a locus of justice for quite distinct reasons and in accordance with quite distinct standards from those employed to evaluate the qualities of outcomes' (p. 74). While outcomebased theories might accept that procedures are instrumentally important, insofar as procedures are a means of achieving just outcomes, outcome-based theories do not regard procedures as inherently or intrinsically important for justice. ${ }^{9}$ In contrast, Ceva (2016) argues for intrinsic proceduralism. Intrinsic proceduralism claims that,

certain procedures are inherently valuable insofar as they are constitutive of inherently valuable forms of human interaction in politics and society; these are interactions in which people are treated in an inherently morally 
acceptable manner because they are given appropriate consideration-they are reckoned with in terms that are fittingly responsive to their status as potential makers of valid claims.

Second, Ceva (2016) grounds moral acceptability in the principles of procedural equality and human dignity. The principle of procedural equality is the principle that all parties to a conflict are equal in a fundamental but minimal sense-that is, they are 'entitled to an equal chance to have their say' (p. 115). The test for whether a procedure or form of social and political interaction is morally acceptable and hence meets the requirements of procedural equality is whether the parties are treated in a manner consistent with the demands of human dignity. Ceva understands dignity, following Jeremy Waldron (and Kant), as a status concept that is grounded in recognition of our human capacities for rational agency, and hence recognition of our rights as rational agents to make claims against others (pp. 76-77). The demands of human dignity require that no individual is regarded or treated by public institutions and office holders as morally inferior to others, that each person is regarded as having the status of a potential maker of valid claims, and that each person is entitled to a chance to voice their claims that is not inferior to the chance granted to others (p. 125). Having an equal chance does not mean 'that the outcome is equally influenced or shaped by all views in an equal manner'; rather, it means that all claims are voiced on an equal footing (p. 132). She cites the principle of due process in legal contexts as an instantiation of this form of dignity and procedural equality:

The very idea that a person has a right to have her say on her own behalf before a public tribunal is a constitutive component of the treatment of a person in accordance with her dignity as it implies that she is recognized as the source of a potentially valid claim that should be aired. From this perspective due process is not only-and perhaps not primarily — valuable as an instrument to reach an accurate verdict (a just outcome) but as it realizes in itself the fundamental normative commitment to treating persons with dignity (with just procedures being constitutive of such a treatment) ${ }^{10}$

Third, Ceva (2016, pp. 115-117) argues that states have a moral duty to design institutions and processes that meet the requirements of procedural equality and interactive justice. Exactly how to meet these requirements will vary depending on the context, because factors that may hinder the realisation of procedural equality need to be taken into account and mitigated. These factors include the effects of material and relational inequalities on individuals' abilities to voice their claims, including the effects of lack of education, being a member of an unpopular minority, being disenfranchised, socially marginalised, and so on.

Finally, Ceva argues that intrinsic proceduralism provides a stronger argument for the value of procedures than expressive forms of proceduralism. ${ }^{11}$ Many 
relational egalitarian theories, as discussed above, are expressivist in maintaining that state institutions have special responsibilities to ensure that their processes express respect for citizens, and that, in their interactions with citizens, office holders treat individuals in ways that convey attitudes of equal respect. On the expressivist view, respect (or disrespect) are not only conveyed but also embodied in the processes and procedures by which citizens interact with social institutions and authorities. In other words, procedures matter because of the messages they embody about a person's social standing in the eyes of authorities. Procedures that express respect publicly acknowledge a person's standing as a moral and social equal. Ceva argues, however, that procedural equality does not simply express or promote normative commitments to human dignity, it actually realises those commitments and bestows dignity. This is because just procedures, such as due process, confer a normative status on participants in those procedures, a normative status they would not otherwise have and that is constituted by the procedures themselves. I think Ceva is correct that procedurally just processes can confer or bestow, as well as express, dignitary standing. However, I think that one way in which they confer this standing is by virtue of embodying a message about citizens' social and moral equality. For this reason, I am not sure that as much hangs on the distinction between expressive and intrinsic proceduralism as Ceva claims.

Ceva's understanding of dignity as grounded in rational agency is, however, quite Kantian, and so I think the notion of respect for dignity that is central to her account of procedural justice differs in important ways from the understanding of respect that is at stake in both relational egalitarianism and relational models of procedural justice in the empirical literature. Although relational egalitarianism is grounded in the idea of moral equality, it claims that social equality is a central requirement of justice, while inequalities of social standing that undermine the social conditions required for individual freedom, autonomy and self-respect are inherently unjust. So for relational egalitarians, respect for others' dignity is not just a matter of respecting their status as rational agents. Respecting others' dignity is also a matter of respecting their rights to be included as equal participants in a social community, conceived of as 'a system of cooperation and affiliation among equals' (Anderson 2008, p. 143). Further, inclusion in a social community, as an equal participant is a condition for self-respect.

For this reason, I think the relational egalitarian view may be closer than Ceva's view to Tyler's relational notions of respect and dignity, which are based on group-value models of identity. However, as outlined above, Tyler's groupvalue account is psychological-he says, 'people are concerned about their status in groups because high status within a group validates their own self-identity' (Tyler \& Lind 1992, p. 141) and their sense of self-worth. Relational egalitarianism, I have argued, is both psychological and normative. Certainly, there are psychological reasons why, as social beings, we value others' recognition of our status as equal participants in a social community. But relational egalitarians also 
claim that we are normatively entitled to the conditions for that recognition and hence to the social bases of self-respect. That is why social processes that deny those conditions to individuals or social groups are unjust.

To sum up the argument presented in this section, I have suggested that Ceva presents an important argument for procedural justice as a distinct locus of justice. She also develops a normative argument for why state institutions have an obligation to design and enact procedurally just processes - that is, processes that express and bestow dignity and respect on those who are subject to these processes. However, I have suggested that her account of respect is more dignitarian than relational. In the next section, I will briefly outline two philosophical analyses that will help to further clarify the differences between dignitarian and relational conceptions of respect and self-respect. ${ }^{12}$

\subsection{Respect, self-respect, and procedural justice}

The conception of respect for dignity that underpins Ceva's account of procedural justice resonates with Stephen Darwall's (1977) influential analysis of recognition respect. Darwall distinguishes two kinds of respect: appraisal and recognition respect. Appraisal respect for someone as a person is respect or esteem for that person's character as a moral agent. Appraisal respect for a person is therefore responsive to merit or excellences of character $(1977$, p. 39). Because it is responsive to persons' moral qualities, there is no moral obligation to regard all persons with appraisal respect; such respect is only due when it is warranted. Recognition respect for persons, by contrast, is categorical and is the kind of respect that is owed to all persons in virtue of their status and dignity as persons. It involves giving due weight to the recognition that someone is a person, that is, a free and rational agent, in the way one treats and acts towards her. In later work $(2004,2006)$, Darwall adds to this the idea that recognition respect involves recognition and acknowledgement of another person's second-personal authority to demand that she be respected as a person. It thus involves 'addressing the other in a way that presupposes and reciprocally recognizes the equal dignity, hence mutual accountability, of addresser and addressee' (2004, p. 55). Relational egalitarians would argue that the expectation that one is due this kind of recognition respect is normatively grounded in the requirement to respect others as moral and social equals. The expectation that one is due recognition respect, I suggest, also underpins the expectation of respect that emerges as a strong theme in the empirical research on PJ.

However, while Darwall's analysis of respect is relational to the extent that it places second-personal interactions at its heart, it overlooks the social and political context of these interactions and the way they are shaped by dynamics of social power and inequality. ${ }^{13}$ Hence, it overlooks the ways in which these dynamics can shape both individuals' second-personal authority to demand respect and their sense of self-respect-that is, their sense of themselves as respect-worthy persons 
whose lives have value. Robin Dillon's (1997) analysis of self-respect is more attuned to these relational dynamics. She argues that,

the nature and meaning of self-respect and how it is constituted and expressed, both at the level of individual experience and at the level of concept, is a function of social relationships and the structure and functioning of the social institutions among which we live.

Dillon draws on Darwall to distinguish two kinds of self-respect: appraisal and recognition self-respect. Appraisal self-respect is 'confidence in one's merit as a person' (p. 231), or the evaluative appraisal of oneself as living up to the standards of one's normative self-conception. Recognition self-respect involves respecting oneself as a moral agent, and regarding oneself as having equal moral worth and standing, or to use Darwall's later terminology, as having the secondpersonal authority to demand that others respect one as a person. Dillon argues, however, that the ground for both appraisal and recognition self-respect is a more fundamental kind of self-respect, basal self-respect, which is a basic emotional and experiential attitude toward oneself and one's life as having intrinsic value or worth. This basic value orientation to oneself 'is relational, interactional and institutionally structured and enacted' (1997, p. 245) and can be damaged by dysfunctional interpersonal relationships, and by experiences of social marginalisation and exclusion.

Dillon's claim about basal self-respect being relational, interactional, and institutionally structured and enacted resonates with group-value theory. It provides a complementary explanation of why people are so sensitive to the messages about their status conveyed by group processes and by how they are treated by persons in positions of authority. Dillon's emphasis on the impact of social dynamics of power and inequality on people's sense of self-respect is also borne out in the empirical research literature on PJ. Tyler and Blader (2003, p. 358), for example, argue that for members of minority social groups who are subject to stereotyping and stigmatisation, the quality of both the decision-making and interpersonal treatment they receive at the hands of authorities has direct impacts on their sense of identity, especially their sense of self-worth and self-esteem. Fair and neutral decision-making by authorities communicates to members of minority groups that they will not be subject to prejudice and stereotyping. Being treated politely and with respect communicates the message that they are valued members of society. By contrast, practices such as racial profiling can 'communicate marginality and exclusion from important protections' that are extended to members of other social groups, such as freedom from arbitrary arrest and detention (2003, p. 359), thereby undermining what Dillon refers to as basal self-respect, as well as prompting reactions of anger and alienation. ${ }^{14}$

Critics of expressivist views, such as Ceva argue that the expressivist appeal to the negative effects of unfair and disrespectful treatment on citizens' sense of self-respect and self-worth is vulnerable to empirical contingencies. ${ }^{15}$ Different 
people may react in different ways to such treatment, and these different reactions may also be connected to contextual, cultural or historical factors. Tyler's work suggests, however, that people's reactions may be less variable than Ceva thinks. Furthermore, to the extent that such differences exist, Dillon's relational analyses of recognition self-respect (as respect for one's equal moral worth and standing), and of basal self-respect (as a basic emotional and experiential attitude toward oneself and one's life as having intrinsic value or worth) show that the existence of any such differences does not undermine the normative force of the obligation to treat others in ways that promote self-respect.

The relational analysis of self-respect thus provides further support for the normative claim that authorities should embed PJ in their interactions with citizens because it is morally right that citizens are treated in a procedurally just manner. Governmental officials, such as police, members of the judiciary, and administrative officers in areas such as social welfare, are representatives of institutions that exercise considerable coercive power over people's lives. Many citizens who are subject to the determinations of such officials may be socially disadvantaged or marginalised and predisposed to be mistrustful of government institutions. Moreover, they may not regard themselves as having the second-personal authority to demand respectful treatment from officials. Even citizens who are not disadvantaged in terms of their social standing may feel similarly powerless in the context of judicial or administrative decision-making processes that affect their rights and welfare. The empirical research on PJ shows that this sense of powerlessness can damage not only people's sense of self-respect but also their confidence in the neutrality and trustworthiness of governmental officials and institutions. A commitment to procedural justice entails a commitment to processes that support and promote self-respect by expressing respect for individual citizens as moral and social equals. Enacting this commitment requires taking seriously the institutional power wielded by officials, and developing processes that keep this power in check, and that aim to convey the sense that officials and the citizens who are subject to their determinations are mutually accountable. This requires processes that demonstrate officials' neutrality, trustworthiness, willingness to listen, commitment to justice, and concern for the welfare of those who appear before them.

\subsection{Conclusion}

The empirical research on procedural justice provides strong evidence that the four factors of respect, neutrality, trustworthiness and voice are central to citizens' judgements about whether institutions and authorities are legitimate in the descriptive or sociological sense. Social psychologists do not presume that their findings provide criteria for legitimacy in the normative philosophical sense. Nevertheless, in this chapter I have argued that recent work in normative political philosophy lends support to the idea that legitimacy in the descriptive sense may converge with legitimacy in the normative sense. Relational egalitarian theory provides normative support for citizens' expectations that they should be treated fairly and 
with respect. It grounds these expectations in the idea that a central requirement of justice is that citizens should be treated as moral and social equals. Ceva's work provides support for the view that procedural justice is a distinct domain of justice, as well as for the claim that procedures are inherently normatively important. Darwall's analysis of recognition respect explicates what respect for a person as a moral equal entails, while Dillon's relational analysis of self-respect underscores the normative connection between social equality and self-respect. If the argument developed in this chapter is persuasive it shows that, to the extent that the four factors of PJ satisfy citizens' expectations for fair and respectful treatment, institutions and authorities that embed PJ in their processes and interpersonal interactions with citizens will count as both descriptively and normatively legitimate.

\section{Notes}

1 Thanks to Denise Meyerson and Therese MacDermott for their very helpful comments on earlier versions of this chapter. Thanks also to participants at a workshop on procedural justice held at Macquarie University in 2018. Research for this chapter was funded by the Australian Research Council's Discovery Project funding scheme (DP1701009600: 'A Relational Theory of Procedural Justice').

2 While the empirical research on procedural justice is voluminous, my discussion in this chapter has been most influenced by the work of Tom Tyler and Alan Lind. See especially Tyler and Lind (1992).

3 However, see Bottoms and Tankebe's contribution to this volume (Chapter 4) for a more qualified endorsement of this claim.

4 In referring to an 'instrumental' justification here I mean to contrast it with a normative justification in the philosophical sense, as explained in the text that follows. However, it is important to clarify that the term 'instrumental' is often used in the social psychology literature to refer to approaches to authority and legitimacy which assume that people are motivated to obey the law primarily from selfinterested concerns. In this context, 'instrumental' approaches to authority and legitimacy are typically contrasted with 'relational' and 'normative' approaches to procedural justice, which claim that relying on people's instrumental (i.e. self-interested) motives to obey the law is not an effective way to govern, and that encouraging belief in the legitimacy of the law via PJ is more effective. Tina Murphy's contribution to this volume (Chapter 1) understands the term 'instrumental' in this way. For a more detailed analysis, see, e.g., Tyler and Lind (1992, 119-121), who refer to 'social exchange' theories of legitimacy as instrumental in this sense. According to Tyler and Lind, social exchange theories hold that people are primarily motivated by self-interested concerns and hence people evaluate social relationships and interactions in terms of their costs and benefits. Thus, people's perceptions of the legitimacy or otherwise of procedures and authorities are tied 'to the extent to which the authority's decisions and the procedures used to generate those decisions are personally favourable', as well as the transaction costs and benefits of those procedures (1992, p. 120). In their chapter in this volume (Chapter 4), Bottoms and Tankebe provide a useful and related analysis of the way social psychologists understand the terms 'instrumental' and 'normative'.

5 There are parallels between Anderson's argument and Habermas' analysis of the importance of democratic participatory procedures for political and legal legitimacy. For discussion of the relevance of democratic or 'bottom up' participatory procedures for procedural justice, see Sarah Sorial's contribution to this volume (Chapter 6). 
6 In her contribution to this volume (Chapter 10), Natalie Stoljar argues that the feeling by members of racially profiled groups that the justice system is unfair and disrespectful is justified, because racial profiling both expresses and constitutes disrespectful treatment. This is another powerful example of how the processes and procedures by which authorities interact with citizens can embody messages of disrespect.

7 This expectation of normative entitlement to be treated as a moral and social equal might be a form of what Bottoms and Tankebe, in their contribution to this volume, refer to as a 'basic legitimation expectation'. (See Chapter 4).

$8 \mathrm{My}$ discussion focuses primarily on the account of interactive justice developed in Ceva (2016). However, see also Ceva's contribution to this volume (Chapter 8).

9 In her contribution to this volume (Chapter 7), Denise Meyerson also provides a detailed argument against instrumentalist, outcome-based accounts of the value of procedures.

10 In her contribution to this volume (Chapter 8), Ceva provides a more detailed analysis of due process in legal contexts as an instantiation of interactive justice.

11 For Ceva's critique of expressivism, see Ceva (2016, pp. 82-84). Her argument for intrinsic proceduralism is developed in detail in Ceva (2016, esp. pp. 92-107). See also her contribution to this volume (Chapter 8).

12 Some of the discussion in the following section draws on material in Meyerson and Mackenzie (2018).

13 Drawing on Darwall's work, in her contribution to this volume (Chapter 10), Natalie Stoljar argues that racial profiling constitutes a form of both recognition and appraisal disrespect. Racial profiling provides a salient example of why relational theories of justice should attend not just to second-personal interactions but the way these interactions are shaped by dynamics of social power.

14 See also the findings of empirical studies reported in Tyler (2001 and 2009), which indicate that perceived quality of treatment is directly linked to the extent to which members of minority groups are supportive of law and legal authorities.

15 See Ceva's contribution to this volume (Chapter 8).

\section{References}

Anderson, E 1999, 'What is the point of equality?', Ethics, vol. 109, no. 2, pp. 287-337.

Anderson, E 2008, 'Expanding the egalitarian toolbox: equality and bureaucracy', Proceedings of the Aristotelian Society, Supplementary Volumes, vol. 82, pp. 139-160.

Anderson, E 2009, 'Towards a non-ideal, relational methodology for political philosophy', Hypatia, vol. 24, no. 4, pp. 130-145.

Ceva, E 2016, Interactive justice: a proceduralist approach to value conflict in politics, Routledge, New York/London.

Darwall, SL 1977, 'Two kinds of respect.' Ethics, vol. 88, no. 1, pp. 36-49.

Darwall, SL 2004, 'Respect and the second-person standpoint', Proceedings and Addresses of the American Philosophical Association, vol. 78, no. 2, pp. 43-59.

Darwall, SL 2006, The second-person standpoint: morality, respect, and accountability, Harvard University Press, Cambridge.

Dillon, RS 1997, 'Self-respect: moral, emotional, political', Ethics, vol. 107, no. 2, pp. 226-249.

Garrau, M \& Laborde C 2015, 'Relational equality, non-domination, and vulnerability', in C Fourie, F Schuppert \& I Wallimann-Helmer (eds.), Social equality: on what it means to be equals, Oxford University Press, New York. 
Jackson, J 2018, 'Norms, normativity, and the legitimacy of justice institutions: international perspectives', Annual Review of Law and Social Science, vol. 14, no. 1, pp. 17.1-17.21. doi: 10.1146/annurev-lawsocsci-110316-113734

Levitov, A 2016, 'Normative legitimacy and the state', retrieved from Oxford Handbooks Online, online publication date October 2016. doi: 10.1093/oxfor dhb/9780199935307.013.131.

Meyerson, D \& Mackenzie, C 2018, 'Procedural justice and the law', Philosophy Compass, vol. 13, no. 12, e12548, pp. 1-11. doi: 10.1111/phc3.12548

Rawls, J 1993, Political liberalism, Columbia University Press, New York.

Scheffler, S 2003, 'What is egalitarianism?' Philosophy and Public Affairs, vol. 31, no. 1, pp. 5-39.

Schemmel, C 2011, 'Distributive and relational equality', Philosophy, Politics \& Economics, vol. 11, no. 2, pp. 123-148.

Schemmel, C. 2015, 'Social equality—or just justice?', in C Fourie, F Schuppert \& I Wallimann-Helmer (eds.), Social equality: on what it means to be equals, Oxford University Press, New York.

Sheffler, S 2015, 'The practice of equality', in C Fourie, F Schuppert \& I WallimannHelmer (eds.), Social equality: on what it means to be equals, Oxford University Press, New York.

Tyler, T 2001, 'Public trust and confidence in legal authorities: what do majority and minority group members want from the law and legal institutions?', Behavioral Sciences and the Law, vol. 19, no. 2, pp. 215-235.

Tyler, T 2009, 'Majority and minority perspectives on justice and trust: Is there a consensus on goals?', in S Demoulin, JP Leyens \& JF Dovidio (eds.), Intergroup misunderstandings: impact of divergent social realities, Psychology Press, New York/London, pp. 233-249.

Tyler, T \& Lind, A 1992, 'A relational model of authority in groups', in MP Zanna (ed.), Advances in experimental social psychology, vol. 25, Academic Press, San Diego, pp. 115-191.

Tyler, TR \& Blader, SL 2003, 'The group engagement model: procedural justice, social identity, and cooperative behavior'. Personality and Social Psychology Review, vol. 7, no. 4, pp. 349-361.

Wolff, J 1998, 'Fairness, respect and the egalitarian ethos', Philosophy and Public Affairs, vol. 27, no. 2, pp. 97-122.

Wolff, J 2015, 'Social equality and social inequality', in C Fourie, F Schuppert \&I Wallimann-Helmer (eds.), Social equality: on what it means to be equals, Oxford University Press, New York. 